\title{
Analytical high performance liquid chromatography method for estimating the combination of aspirin and omeprazole in bulk and tablet dosage form
}

\author{
Gopikrishna YENDURI ${ }^{1}$ *, Srinivasu NAVULURI ${ }^{1}$ \\ 1 Division of Chemistry, Department of Sciences and Humanities, Vignan's Foundation for Science, Technology and \\ Research University, Guntur, India. \\ * Corresponding Author. E-mail: ygk.phd@gmail.com, hod_sh@vignanuniversity.org (G.Y.); Tel: +91-990 831 32 50; \\ ORCID No: 0000-0003-3972-8819.
}

Received: 16 May 2017 / Revised: 5 September 2017 / Accepted: 7 September 2017

\begin{abstract}
A HPLC method was developed for the estimation of aspirin and omeprazole simultaneously in bulk drug and tablet dosage forms. $0.1 \mathrm{M}$ potassium dihydrogen phosphate and acetonitrile in the ratio of $55: 45 \mathrm{v} / \mathrm{v}$ at $\mathrm{pH}$ of 4.5 was used successfully as the mobile phase for the analysis of the selected drugs. Analysis of the selected drugs was carried out using Zodiac C18 $(150 \times 3.0 \mathrm{~mm}, 5 \mu \mathrm{m})$ column. The calibration range for omeprazole was 0.08-24 $\mu \mathrm{g} / \mathrm{ml}$, whereas, for aspirin was $0.65-195 \mu \mathrm{g} / \mathrm{ml}$. The LOD and LOQ values were; $0.199 \mu \mathrm{g} / \mathrm{ml}$ and $0.65 \mu \mathrm{g} / \mathrm{ml}$ for aspirin, $0.024 \mu \mathrm{g} / \mathrm{ml}$ and $0.080 \mu \mathrm{g} / \mathrm{ml}$ for omeprazole, respectively. The percentage recovery of aspirin and omeprazole was found to be $99.75 \%-99.92 \%$ and $99.46 \%-99.57 \%$, respectively. Percentage relative standard deviation (RSD\%) was found to be in the range of $0.083 \%-0.085 \%$ for aspirin and $0.045 \%-0.047 \%$ for omeprazole. Forced degradation studies (such as alkaline, acidic, oxidative, thermal and photolytic degradation conditions) were performed on tablet sample as per the ICH guidelines. The peaks of degradants are well separated from the main peaks of aspirin and omeprazole. The proposed HPLC method was successfully applied for the quantification of aspirin and omeprazole in its pharmaceutical dosage forms without interference from common excipients.
\end{abstract}

KEYWORDS: Aspirin; omeprazole; forced degradation; stability studies; tablet dosage form.

\section{INTRODUCTION}

Aspirin is a nonsteroidal anti-inflammatory drug used in the temporary relief of various forms of pain and inflammation associated with various conditions [1]. Chemically, it is known as 2-acetyloxybenzoic acid (Figure 1). Commonly, it is also called as acetylsalicylic acid. Aspirin exhibits antipyretic, antirheumatic, analgesic and anticoagulant properties [2,3]. Through inhibiting the activity of cyclooxygenase, aspirin blocks the biosynthesis of prostaglandins [4]. Aspirin is also involved in the prevention of arterial and venous thrombosis by inhibiting platelet aggregation [5].

Omeprazole belongs to proton pump inhibitor group of drugs [6]. Chemically it is described as 5methoxy-2-[[(4-methoxy-3,5-dimethyl-2-pyridinyl)methyl]sulphinyl]-1H-benzimidazole (Figure 1). Omeprazole is generally used for the prophylaxis and management of gastro-duodenal ulcers and symptoms of gastro-oesophageal reflux [7-9]. Omeprazole is also effective in curing erosive esophagitis [10]. In combination with antibiotics, omeprazole could be given to treat gastritis caused by infection with gramnegative microaerophilic bacterium, Campylobacter pylori.

Aspirin and omeprazole are available as combined tablet dosage form for the secondary prevention of cardiovascular disease in patients who are at risk of gastric ulcers induced by aspirin [11, 12]. High performance liquid chromatography (HPLC) has advantages like robust, simple, rapid and efficient tool in quantitative analysis of pharmaceutical substances. To the best of our knowledge, only one UV spectroscopic method has been reported for the simultaneous estimation of aspirin and omeprazole using methanol as solvent [13].

How to cite this article: Yenduri G, Navuluri S. Analytical high performance liquid chromatography method for estimating the combination of aspirin and omeprazole in bulk and tablet dosage form. Marmara Pharm J. 2018; 22 (4): 502-510. 
<smiles>CC(=O)Oc1ccccc1C(=O)O</smiles>

Aspirin<smiles>COc1ccc2[nH]c(S(=O)Cc3ncc(C)c(OC)c3C)nc2c1</smiles>

Omeprazole

Figure 1. Chemical structures of the analyzed drugs.

No HPLC method has been reported for the estimation of aspirin and omeprazole in combination. Stress testing is carried out to find out the stability of the active substance [14]. A best method for indicating stability is one that allows estimation of the drug and resolution of its degradation products. To the best of our knowledge, no stability-indicating analytical HPLC method has been reported for the aspirin and omeprazole combination. The aim of the present study was to establish a stability indicating HPLC method for the simultaneous estimation of aspirin and omeprazole in bulk and in combined tablet dosage form.

\section{RESULTS AND DISCUSSION}

\subsection{Method development}

By using a Zodiac $\mathrm{C} 18$ column $(150 \mathrm{~mm} \times 3.0 \mathrm{~mm}$ i.d, $5 \mu \mathrm{m})$ with temperature maintained at $30^{\circ} \mathrm{C}$, sharp peaks of aspirin and omeprazole with satisfactory separation was achieved. Hence the same column and temperature was used in the present study. To achieve good peak shape and resolution under isocratic conditions, mixtures of acetonitrile and $0.1 \mathrm{M}$ potassium hydrogen phosphate in different combinations with different flow rates and with different $\mathrm{pH}$ were tried on the Zodiac C18 HPLC column. Finally, a binary mixture of $0.1 \mathrm{M}$ potassium dihydrogen phosphate and acetonitrile $(\mathrm{pH}$ of 4.5 - adjusted with orthophosphoric acid) in 55:45 $\mathrm{v} / \mathrm{v}$ proportions with the flow rate of $1 \mathrm{ml} / \mathrm{min}$ was found to be suitable. $20 \mu \mathrm{l}$ injection volume was appropriate in separating aspirin, omeprazole and degradation products. Wavelength of $260 \mathrm{~nm}$ was chosen as analytical wavelength for the estimation of aspirin and omeprazole simultaneously with good sensitivity. Under the optimized chromatographic parameters, the retention time of $3.941 \mathrm{~min}$ and $5.317 \mathrm{~min}$ was obtained for aspirin and omeprazole, respectively.

\subsection{Method validation}

The developed analytical HPLC method was validated as stated by the ICH guidelines [16] for system suitability, selectivity, precision, linearity, accuracy, specificity, robustness, limit of detection (LOD), and limit of quantification (LOQ).

\subsubsection{System suitability}

The system suitability parameters (RSD\% for retention time, RSD\% for peak area, USP resolution, USP theoretical plates and USP tailing factor) were calculated after six replicate injections of standard aspirin and omeprazole solution into the HPLC system. The obtained results are tabulated in Table 1 which is in the acceptable range for aspirin and omeprazole.

\subsubsection{Selectivity}

To evaluate the selectivity of the proposed method, the chromatograms of mobile phase solution (blank), placebo blank and the solution of tablet sample were compared with chromatogram of standard solution of omeprazole and aspirin. The chromatograms are shown in Figure 4. No endogenous peak was observed at the retention time of omeprazole and aspirin in the chromatograms of placebo blank (Figure 2A) and mobile phase blank (Figure 2B). The retention time of omeprazole and aspirin in chromatograms of tablet sample solution (Figure 2C) and standard solution (Figure 2D) are same. The common exipients of tablet dosage form and components of mobile phase were not interfering with the peaks of selected drug combination and thus indicating the selectivity of the proposed method. 
Table 1. Results of system suitability studies.

\begin{tabular}{|c|c|c|c|c|c|}
\hline Sample No. & $\begin{array}{c}\text { Retention } \\
\text { time }\end{array}$ & $\begin{array}{l}\text { Peak } \\
\text { Area }\end{array}$ & $\begin{array}{l}\text { Plate } \\
\text { count }\end{array}$ & $\begin{array}{c}\text { Tailing } \\
\text { factor }\end{array}$ & Resolution \\
\hline \multicolumn{6}{|c|}{ Omeprazole (16 19/ml) } \\
\hline 1 & 5.317 & 515572 & 5224 & 1.15 & 5.21 \\
\hline 2 & 5.299 & 510776 & 5183 & 1.14 & 5.18 \\
\hline 3 & 5.296 & 510236 & 5190 & 1.14 & 5.13 \\
\hline 4 & 5.305 & 515096 & 5169 & 1.14 & 5.15 \\
\hline 5 & 5.304 & 517025 & 5273 & 1.15 & 5.12 \\
\hline Mean & 5.304 & 513741 & 5207 & 1.144 & 5.158 \\
\hline RSD & 0.152 & 0.592 & 0.800 & 0.479 & 0.718 \\
\hline $\begin{array}{l}\text { Recommended } \\
\text { limit }\end{array}$ & $\mathrm{RSD} \leq 2$ & $\mathrm{RSD} \leq 2$ & $>2000$ & $\leq 2$ & $>1.5$ \\
\hline \multicolumn{6}{|c|}{ Aspirin $(130 \mu \mathrm{g} / \mathrm{ml})$} \\
\hline 1 & 3.941 & 377822 & 4976 & 1.17 & - \\
\hline 2 & 3.931 & 373771 & 4940 & 1.17 & - \\
\hline 3 & 3.930 & 376461 & 4985 & 1.16 & - \\
\hline 4 & 3.933 & 371521 & 4913 & 1.16 & - \\
\hline 5 & 3.938 & 376052 & 4932 & 1.17 & - \\
\hline Mean & 3.935 & 375125 & 4949 & 1.166 & - \\
\hline RSD & 0.120 & 0.663 & 0.614 & 0.470 & - \\
\hline $\begin{array}{l}\text { Recommended } \\
\text { limit }\end{array}$ & $\mathrm{RSD} \leq 2$ & $\mathrm{RSD} \leq 2$ & $>2000$ & $\leq 2$ & - \\
\hline
\end{tabular}

\subsubsection{Linearity}

A linear relationship was established by plotting the peak areas (on Y-axis) against the drug concentration in $\mu \mathrm{g} / \mathrm{ml}$ (on $\mathrm{x}$-axis). The concentration range was found to be $0.65-195 \mu \mathrm{g} / \mathrm{ml}$ and $0.08-24$ $\mu \mathrm{g} / \mathrm{ml}$ for aspirin and omeprazole respectively. The linear regression analysis of the data for both drugs gave the following equations:

$$
\mathrm{PA}=2887 \mathrm{x}-192.9\left(R^{2}=0.9996\right) \text { for aspirin }
$$

$$
\mathrm{PA}=32107 \mathrm{x}-191.4\left(R^{2}=0.9998\right) \text { for omeprazole }
$$

Where PA is the peak area of the analyte, $\mathrm{x}$ is the concentration of the drug in $\mu \mathrm{g} / \mathrm{ml}$ and $R^{2}$ is the regression coefficient. The high values of regression coefficients $(>0.999)$ with low intercept values indicate the good linearity of the calibration curves for aspirin and omeprazole.

\subsubsection{Limit of detection (LOD) and limit of quantification (LOQ)}

The smallest amount of drug (LOD) that could be detected was $0.199 \mu \mathrm{g} / \mathrm{ml}$ for aspirin and $0.024 \mu \mathrm{g} / \mathrm{ml}$ for omeprazole. The LOQs were $0.650 \mu \mathrm{g} / \mathrm{ml}$ and $0.080 \mu \mathrm{g} / \mathrm{ml}$ for aspirin and omeprazole. The low values of LOD and LOQ point out the adequate sensitivity of the proposed method for the quantification of aspirin and omeprazole.

\subsubsection{Precision and accuracy}

The proposed method was assessed by studying the accuracy as percent recovery and precision as percent relative standard deviation (RSD\%). Precision and accuracy was determined by analyzing standard solutions of omeprazole $(16 \mu \mathrm{g} / \mathrm{ml})$ and aspirin $(130 \mu \mathrm{g} / \mathrm{ml})$ six times. The peak areas obtained were used to calculate mean recovery and \% RSD. The results are tabulated in Table 2 . The mean recovery and RSD \% values indicated that the developed method could estimate aspirin and omeprazole with good accuracy and precision, respectively. 

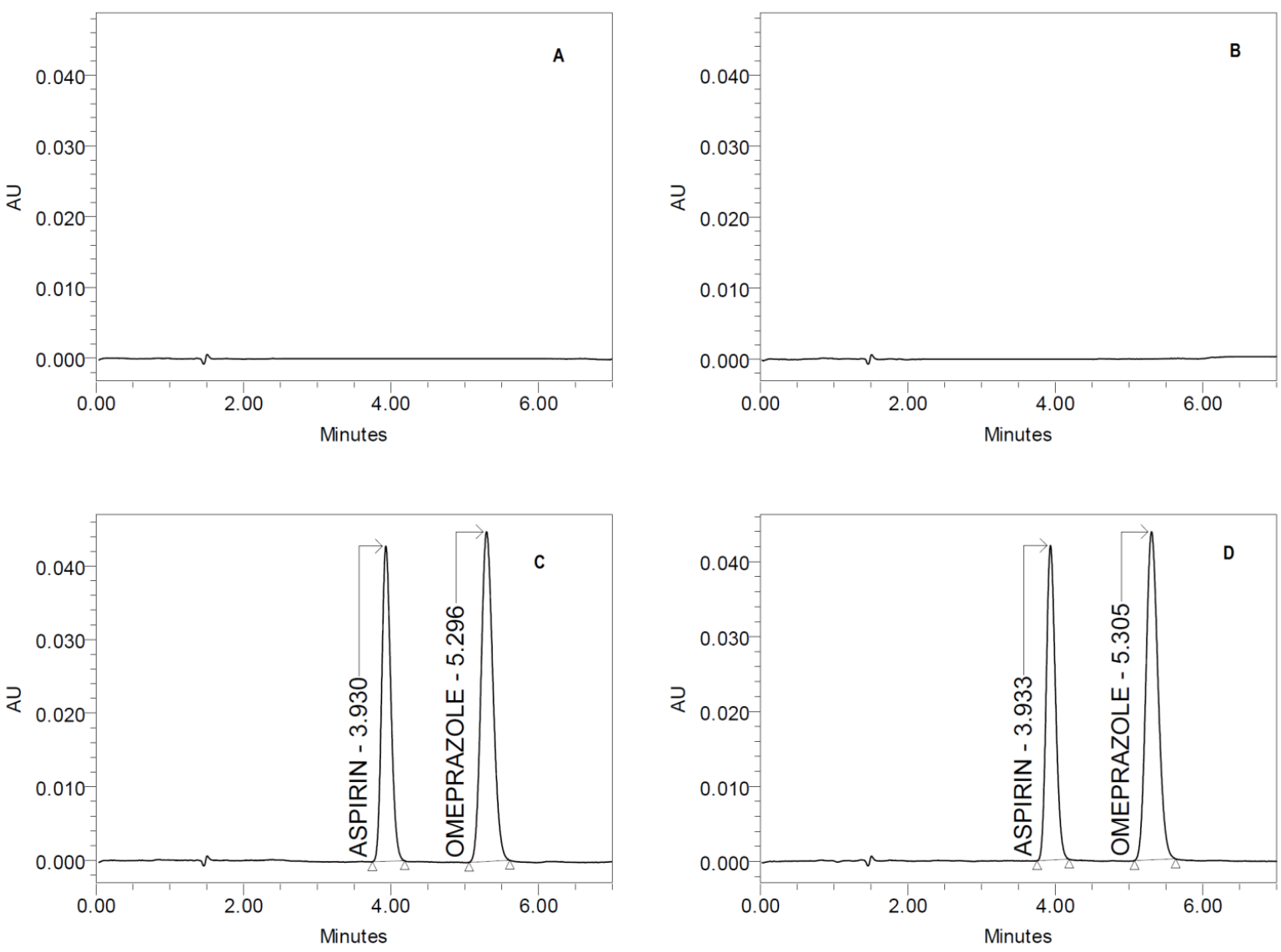

Figure 2. Chromatogram of $[\mathrm{A}]$ Placebo blank [B] Mobile phase blank [C] Tablet sample solution (omeprazole $-16 \mu \mathrm{g} / \mathrm{ml}$ and aspirin - $130 \mu \mathrm{g} / \mathrm{ml}$ ) [D] Standard solution of omeprazole $(16 \mu \mathrm{g} / \mathrm{ml})$ and aspirin $(130 \mu \mathrm{g} / \mathrm{ml})$.

\subsubsection{Recovery studies}

In recovery studies, known amount of standard omeprazole and aspirin was spiked into preanalysed tablet sample solution at three concentration levels. The percent recovery of omeprazole and aspirin was once again determined with the proposed method. The results are tabulated in Table 3 . Recovery values (close to $100 \%$ ) indicated that the developed method was appropriate for accurate quantification of aspirin and omeprazole. Tablet excipients did not interference in the assay of aspirin and omeprazole.

Table 2. Precision and accuracy data for the estimation of omeprazole and aspirin with the proposed test method.

\begin{tabular}{ccccc}
\hline \multirow{2}{*}{ Sample No. } & \multicolumn{2}{c}{ Aspirin $(\mathbf{1 3 0} \mathbf{\mu g} / \mathbf{m l})$} & \multicolumn{2}{c}{ Omeprazole $(\mathbf{1 6} \boldsymbol{\mu g} / \mathbf{m l})$} \\
& Peak area & Recovery $\mathbf{( \% )}$ & Peak area & Recovery $\mathbf{( \% )}$ \\
\hline 1 & 375002 & 99.77 & 513668 & 99.59 \\
2 & 375215 & 99.82 & 513303 & 99.52 \\
3 & 375946 & 100.02 & 513677 & 99.59 \\
4 & 375531 & 99.91 & 513104 & 99.48 \\
5 & 375209 & 99.82 & 513469 & 99.55 \\
6 & 375298 & 99.85 & 513642 & 99.58 \\
Mean & 375439 & $\mathbf{9 9 . 8 8}$ & $\mathbf{5 1 3 4 3 9}$ & $\mathbf{9 9 . 5 4}$ \\
RSD & $\mathbf{0 . 0 8 3}$ & $\mathbf{0 . 0 8 5}$ & $\mathbf{0 . 0 4 7}$ & $\mathbf{0 . 0 4 5}$ \\
\hline
\end{tabular}


Table 3. Recovery results for the estimation of omeprazole and aspirin by using with the proposed test method.

\begin{tabular}{|c|c|c|c|c|c|c|c|c|}
\hline \multirow[b]{2}{*}{$\begin{array}{c}\text { Spiked } \\
\text { Level }\end{array}$} & \multicolumn{4}{|c|}{ Aspirin } & \multicolumn{4}{|c|}{ Omeprazole } \\
\hline & $\begin{array}{l}\text { Added } \\
(\mu \mathrm{g} / \mathrm{ml})\end{array}$ & $\begin{array}{l}\text { Found } \\
(\mu \mathrm{g} / \mathrm{ml})\end{array}$ & $\begin{array}{c}\text { Recovery } \\
(\%)\end{array}$ & $\begin{array}{c}\text { Mean } \\
(\%)\end{array}$ & $\begin{array}{l}\text { Added } \\
(\mu \mathrm{g} / \mathrm{ml})\end{array}$ & $\begin{array}{l}\text { Found } \\
(\mu \mathrm{g} / \mathrm{ml})\end{array}$ & $\begin{array}{c}\text { Recovery } \\
(\%)\end{array}$ & $\begin{array}{c}\text { Mean } \\
(\%)\end{array}$ \\
\hline \multirow{3}{*}{$50 \%$} & 65 & 64.92 & 99.87 & \multirow{3}{*}{99.75} & 8 & 7.96 & 99.47 & \multirow{3}{*}{99.46} \\
\hline & 65 & 64.82 & 99.72 & & 8 & 7.96 & 99.53 & \\
\hline & 65 & 64.79 & 99.68 & & 8 & 7.95 & 99.39 & \\
\hline \multirow{2}{*}{$100 \%$} & 130 & 129.79 & 99.84 & \multirow{3}{*}{99.92} & 16 & 15.94 & 99.60 & \multirow{3}{*}{99.55} \\
\hline & 130 & 129.98 & 99.99 & & 16 & 15.93 & 99.53 & \\
\hline \multirow{4}{*}{$150 \%$} & 130 & 129.93 & 99.95 & & 16 & 15.92 & 99.52 & \\
\hline & 195 & 194.47 & 99.73 & \multirow{3}{*}{99.75} & 24 & 23.89 & 99.53 & \multirow{3}{*}{99.57} \\
\hline & 195 & 194.44 & 99.71 & & 24 & 23.89 & 99.55 & \\
\hline & 195 & 194.64 & 99.81 & & 24 & 23.91 & 99.64 & \\
\hline
\end{tabular}

\subsubsection{Robustness}

The effects of small changes in the mobile phase flow rate $(1.0 \pm 0.1 \mathrm{ml} / \mathrm{min})$, temperature of column $\left(30 \pm 5{ }^{\circ} \mathrm{C}\right)$, acetonitrile ratio $(55 \pm 5 \%), \mathrm{pH}$ of the mobile phase $(4.5 \pm 0.2)$ and detection wavelength $(260 \pm 2$ $\mathrm{nm}$ ) on the system suitability parameters were examined. The robustness of the method was determined at concentrations of $130 \mu \mathrm{g} / \mathrm{ml}$ for aspirin and $16 \mu \mathrm{g} / \mathrm{ml}$ for omeprazole, respectively. From the results (Table 4), it was found that slight changes in flow rate of the mobile phase, temperature of the column, acetonitrile ratio, $\mathrm{pH}$ of the mobile phase and detection wavelength had no significant influence on the system suitability parameters, confirming the method robustness.

Table 4. Method robustness results.

\begin{tabular}{|c|c|c|c|c|c|c|}
\hline \multirow[b]{2}{*}{ Parameter } & \multicolumn{3}{|c|}{ Aspirin (130 $\mu \mathrm{g} / \mathrm{ml})$} & \multicolumn{3}{|c|}{ Omeprazole (16 $\mu \mathrm{g} / \mathrm{ml})$} \\
\hline & $\begin{array}{c}\text { USP } \\
\text { Tailing }\end{array}$ & $\begin{array}{c}\text { USP Plate } \\
\text { Count }\end{array}$ & $\begin{array}{c}\text { USP } \\
\text { resolution }\end{array}$ & $\begin{array}{c}\text { USP } \\
\text { Tailing }\end{array}$ & $\begin{array}{c}\text { USP Plate } \\
\text { Count }\end{array}$ & $\begin{array}{c}\text { USP } \\
\text { resolution }\end{array}$ \\
\hline Flow rate: $1.0+0.1 \mathrm{ml} / \mathrm{min}$ & 1.20 & 4385 & - & 1.18 & 4667 & 4.93 \\
\hline Flow rate: $1.0-0.1 \mathrm{ml} / \mathrm{min}$ & 1.28 & 3438 & - & 1.25 & 3585 & 4.30 \\
\hline Temperature: $30+5^{\circ} \mathrm{C}$ & 1.23 & 4367 & - & 1.20 & 4611 & 4.90 \\
\hline Temperature: $30-5^{\circ} \mathrm{C}$ & 1.27 & 3412 & - & 1.26 & 3560 & 4.28 \\
\hline Acetonitrile ratio: $55+5 \%$ & 1.23 & 4468 & - & 1.17 & 4695 & 4.68 \\
\hline Acetonitrile ratio: 55 - 5\% & 1.17 & 4398 & - & 1.21 & 4718 & 4.72 \\
\hline $\mathrm{pH}$ of mobile phase $4.5+0.2$ & 1.19 & 4365 & - & 1.16 & 4767 & 4.80 \\
\hline $\mathrm{pH}$ of mobile phase $4.5-0.2$ & 1.24 & 4457 & - & 1.19 & 4911 & 4.95 \\
\hline Detection wavelength: $260+2 \mathrm{~nm}$ & 1.19 & 5217 & - & 1.17 & 5287 & 5.27 \\
\hline Detection wavelength: $260-2 \mathrm{~nm}$ & 1.17 & 5319 & - & 1.25 & 4492 & 5.39 \\
\hline
\end{tabular}

\subsubsection{Specificity}

Forced degradation studies were done on omeprazole and aspirin tablet sample solution to establish the specificity (non analyte interference) and stability indicating nature of the proposed method. The results of degradation studies are shown in Table 5 . Omeprazole and aspirin are affected by acidic hydrolysis, alkaline hydrolysis, oxidative degradation, thermal degradation and photo degradation conditions. This shows that the selected drugs were sensitive to all the stress conditions applied. The percentage degradation of both the dugs was more in acidic hydrolysis and less in photo degradation condition (Table 5). Two degradation peaks were observed in oxidative degradation (Figure 3C) and photo degradation (Figure 3E) conditions. One degradation peak was observed in the remaining other conditions (Figures 3A, 3B and 3D). The peaks of all degradation products were satisfactorily separated from the peaks of omeprazole and aspirin, thus the method was proven to be specific. 
The consequence of the presence of degradation products on the purity of omeprazole and aspirin peaks was studied. The purity of the omeprazole and aspirin peaks was proved using the photodiode array detector by obtaining purity threshold greater than purity angle (Table 5). Therefore, the proposed method was found to be stability indicating.

Table 5. Degradation data of omeprazole and aspirin under stress conditions.

\begin{tabular}{|c|c|c|c|c|c|c|c|}
\hline $\begin{array}{c}\text { Stress condition } \\
\text { applied }\end{array}$ & $\begin{array}{l}\text { Drug } \\
\text { Name }\end{array}$ & $\begin{array}{c}\text { Peak } \\
\text { area }\end{array}$ & $\begin{array}{c}\text { Assay } \\
(\%)\end{array}$ & $\begin{array}{c}(\%) \text { of } \\
\text { Degradation }\end{array}$ & $\begin{array}{l}\text { Purity } \\
\text { angle }\end{array}$ & $\begin{array}{c}\text { Purity } \\
\text { threshold }\end{array}$ & $\begin{array}{l}\text { Retention time } \\
\text { of degradants }\end{array}$ \\
\hline \multirow{2}{*}{$\begin{array}{l}\text { Acid } \\
(0.1 \text { N HCl) }\end{array}$} & Asp & 349209 & 92.91 & 7.09 & 0.17 & 0.241 & \multirow[t]{2}{*}{6.294} \\
\hline & Ome & 478469 & 92.76 & 7.24 & 0.175 & 0.236 & \\
\hline \multirow{2}{*}{$\begin{array}{l}\text { Base } \\
(0.1 \mathrm{~N} \mathrm{NaOH})\end{array}$} & Asp & 350531 & 93.26 & 6.74 & 0.171 & 0.244 & \multirow[t]{2}{*}{6.270} \\
\hline & Ome & 479104 & 92.88 & 7.12 & 0.193 & 0.238 & \\
\hline \multirow{2}{*}{$\begin{array}{l}\text { Oxidation } \\
\left(30 \% \mathrm{H}_{2} \mathrm{O}_{2}\right)\end{array}$} & Asp & 352946 & 93.9 & 6.1 & 0.184 & 0.244 & \multirow{2}{*}{$2.488 \& 6.268$} \\
\hline & Ome & 487303 & 94.47 & 5.53 & 0.107 & 0.235 & \\
\hline \multirow{2}{*}{$\begin{array}{l}\text { Dry heat } \\
\left(105^{\circ} \mathrm{C}\right)\end{array}$} & Asp & 356215 & 94.77 & 5.23 & 0.19 & 0.248 & \multirow[t]{2}{*}{6.225} \\
\hline & Ome & 481677 & 93.38 & 6.62 & 0.105 & 0.239 & \\
\hline \multirow{2}{*}{$\begin{array}{l}\text { Photolytic } \\
\text { (Sun light) }\end{array}$} & Asp & 359002 & 95.51 & 4.49 & 0.177 & 0.245 & \multirow{2}{*}{$4.633 \& 6.191$} \\
\hline & Ome & 489668 & 94.93 & 5.07 & 0.102 & 0.234 & \\
\hline
\end{tabular}

\subsection{Application of the proposed HPLC assay method}

The commercially available combined tablet dosage of aspirin and omeprazole (Yosprala tablets) were subjected to the analysis by the proposed HPLC method. The mean percentage recovery, relative to the labeled amounts, obtained by the proposed HPLC method was $99.92 \pm 0.076$ for aspirin and $99.55 \pm 0.063$ for omeprazole (Table 6). This indicated accuracy and precision in the combined analysis of aspirin and omeprazole by the proposed method.

\section{CONCLUSION}

An isocratic, simultaneous and HPLC method with photodiode array detection for the estimation of omeprazole and aspirin has been developed. The developed method holds an acceptable degree of system suitability, selectivity, robustness, precision and accuracy in accordance with international guidelines. The chromatographic elution is done in a short time $(<7 \mathrm{~min})$ with good sensitivity. The proposed method can adequately separate omeprazole, aspirin and their stress degradation products. The components of mobile phase, common tablet excipients and stress degradation products did not interfere with the assay. Therefore, the present HPLC method can be helpful for estimating the concentration of omeprazole and aspirin simultaneously in tablet dosage forms and bulk drugs in quality control laboratories.

\section{MATERIALS AND METHODS}

\subsection{Instrumentation}

The chromatographic separation followed by photodiode array detection were achieved by employing Waters 2695 alliance model HPLC system combined with Waters 2998 photo diode array detector. Waters Empower2 version software was used to control the instrument and processing of the data. The Waters 2695 alliance HPLC system used in the present analysis comprised an autosampler injector, quaternary pump and column heater. 

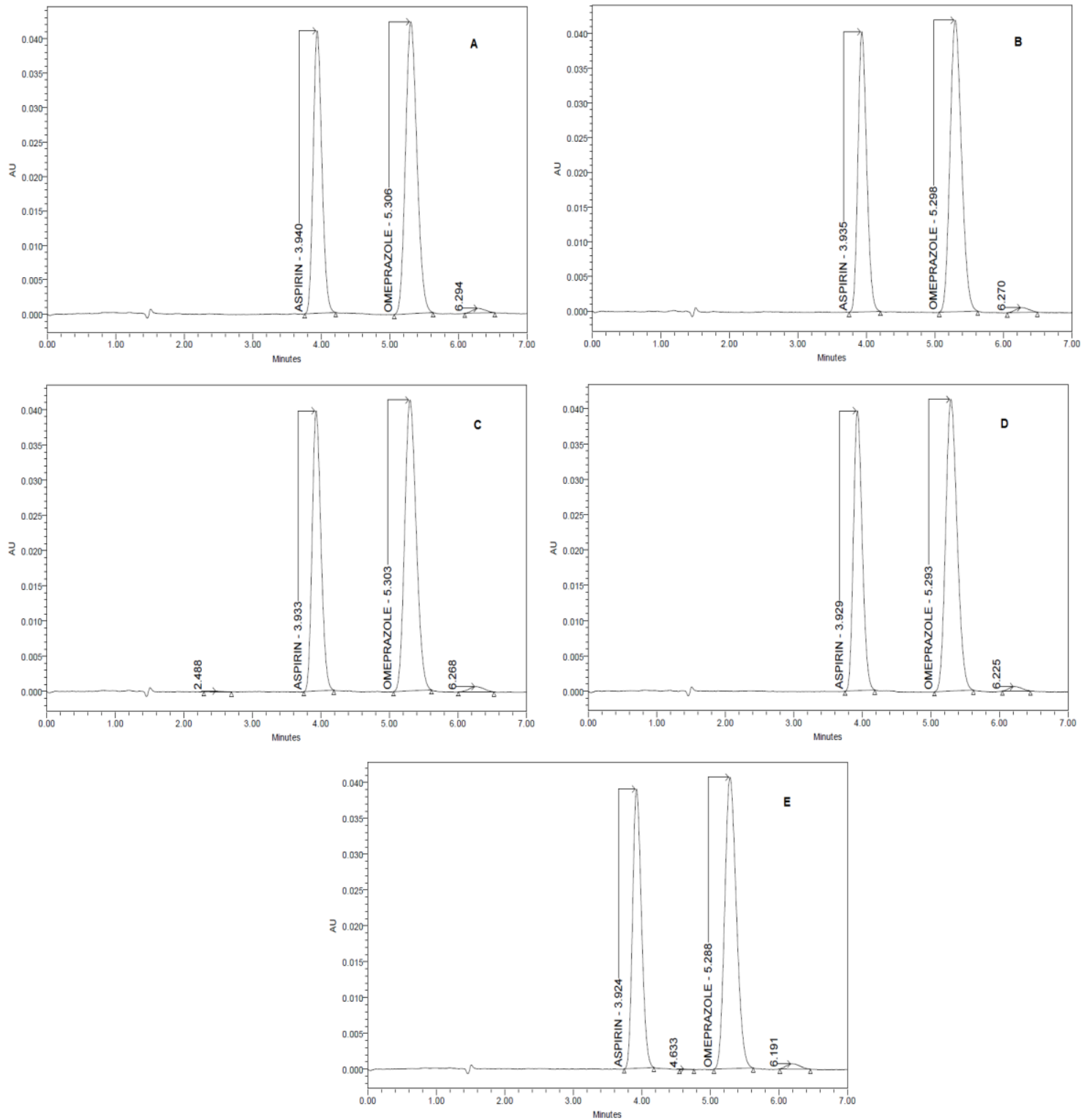

Figure 3. Chromatogram of [A] acid degraded solution [B] Alkaline degraded solution [C] Oxidative degraded solution [D] Thermal degraded solution [E] Photo degraded solution.

\subsection{Chemicals, reference standards and tablet dosage form}

Aspirin and omeprazole reference standards were obtained from Lara Drugs Private Limited (Telangana, India). Yosprala tablets (Aralez Pharmaceuticals US Inc. Princeton, NJ) labeled to contain $325 \mathrm{mg}$ aspirin and $40 \mathrm{mg}$ omeprazole was employed in the present study. Milli-Q water (Millipore with $0.45 \mu$ filter) was used all through the experiments. Potassium dihydrogen phosphate, orthophosphoric acid, hydrogen peroxide, hydrochloric acid and sodium hydroxide of analytical grade were acquired from SD. Fine Chemicals Ltd., Mumbai, India. HPLC gradient grade acetonitrile was from Merck India Ltd (Mumbai, India).

\subsection{Chromatographic conditions}

The chromatographic conditions maintained were Zodiac C18 $(150 \mathrm{~mm} \times 3.0 \mathrm{~mm}$ i.d., with particle size of $5 \mu \mathrm{m}$ ) analytical HPLC column as stationary phase, column was kept at the temperature of $30^{\circ} \mathrm{C}$, aqueous solution of $0.1 \mathrm{M}$ potassium dihydrogen phosphate and acetonitrile (55:45 v/v, $\mathrm{pH} 4.5$ - adjusted with diluted orthophosphoric acid) as mobile phase with the flow rate of $1.0 \mathrm{ml} / \mathrm{min}, 20 \mu \mathrm{l}$ of injection volume and wavelength at $260 \mathrm{~nm}$ as detection analytical wavelength. The mobile phase was filtered through $0.45 \mu \mathrm{m}$ pore size membrane filter and sonicated for $20 \mathrm{~min}$ for degassing before the analysis. 
Table 6. Results of analysis of the selected drug combination in tablet dosage forms by the proposed method.

\begin{tabular}{lcc}
\hline Drug & Aspirin & Omeprazole \\
\hline Labeled & 325 & 40 \\
Amount $(\mathbf{m g})$ & 324.47 & 39.85 \\
Found & 324.95 & 39.82 \\
( $\boldsymbol{g} / \mathrm{ml})$ & 324.82 & 39.8 \\
\hline Mean $(\mu \mathrm{g} / \mathrm{ml})$ & 324.74 & 39.82 \\
Recovery $(\%)$ & 99.92 & 99.55 \\
RSD $(\%)$ & 0.076 & 0.063 \\
\hline
\end{tabular}

\subsection{Stock standard solution}

Accurately weighed $325 \mathrm{mg}$ of aspirin standard and $40 \mathrm{mg}$ of omeprazole standard was transferred in to a $50 \mathrm{ml}$ volumetric flask. $20 \mathrm{ml}$ of mobile phase was added to the flask. The contents of the flask was sonicated for $2 \mathrm{~min}$ to dissolve the drugs completely and diluted with the mobile phase up to mark at $25^{\circ} \mathrm{C}$ temperature. The final concentration of the solution was $6.5 \mathrm{mg} / \mathrm{ml}$ of aspirin and $0.8 \mathrm{mg} / \mathrm{ml}$ of omeprazole. The stock solution was stored at $2-8^{\circ} \mathrm{C}$ until use.

\subsection{Working standard solutions}

The working standard solutions of aspirin and omeprazole were prepared from the above standard stock solution by diluting with the mobile phase to obtain a concentration range of $0.65-195 \mu \mathrm{g} / \mathrm{ml}$ for aspirin and $0.08-24 \mu \mathrm{g} / \mathrm{ml}$ for omeprazole.

\subsection{Construction of calibration curve for aspirin and omeprazole}

$20 \mu \mathrm{l}$ of each working standard solution was injected into the HPLC system in duplicate and chromatographed using the chromatographic conditions mentioned as above. Using least-squares linear regression analysis, calibration curves for aspirin and omeprazole were established separately by plotting the peak areas on y-axis and concentration of the analytes on $x$-axis.

\subsection{Tablet sample preparation}

Ten Yosprala tablets were weighed and finely grinded as powder using mortar pestle. An accurate weight of the grinded powder equivalent to $325 \mathrm{mg}$ of aspirin and $40 \mathrm{mg}$ of omeprazole was transferred into a $50 \mathrm{ml}$ volumetric flask. To this added $20 \mathrm{ml}$ mobile phase and sonicated for $30 \mathrm{~min}$ in an ultrasonic bath. The solution was diluted up to the mark with the mobile phase and filtered through a $0.45 \mu \mathrm{m}$ pore size membrane filter before injection into the HPLC system.

\subsection{Assay of aspirin and omeprazole in tablet dosage form}

$2 \mathrm{ml}$ of above prepared tablet sample solution was transferred into a volumetric flask of $100 \mathrm{ml}$ capacity and made upto the mark with mobile phase to prepare the tablet sample solution containing $130 \mu \mathrm{g} / \mathrm{ml}$ of aspirin and $16 \mu \mathrm{g} / \mathrm{ml}$ of omeprazole. The solution thus prepared was filtered using $0.45 \mu \mathrm{m}$ pore size membrane filter and then analyzed as mentioned under the section 2.6 "Construction of calibration curve for aspirin and omeprazole".

\subsection{Forced degradation of aspirin and omeprazole}

So as to determine the stability indicating property of the proposed method, aspirin and omeprazole were stressed under different conditions to perform the forced degradation studies [15]. Peak purity test was done by using photodiode array detector to look into peak purity. All stress degradation procedures were carried out using $2 \mathrm{ml}$ of the stock tablet sample solution (aspirin $-6.5 \mathrm{mg} / \mathrm{ml}$ and omeprazole $0.8 \mathrm{mg} / \mathrm{ml}$ ).

For acid and base-induced degradation, tablet sample solution was sonicated with $10 \mathrm{ml}$ of $0.1 \mathrm{~N} \mathrm{HCl}$ (for acid-induced degradation) and $0.1 \mathrm{~N} \mathrm{NaOH}$ (for base-induced degradation), separately, at the temperature of $25 \pm 2{ }^{\circ} \mathrm{C}$ for $30 \mathrm{~min}$ and then neutralized to $\mathrm{pH} 7.0$. For oxidative degradation, tablet sample solution was sonicated for $30 \mathrm{~min}$ using $10 \mathrm{ml}$ of $30 \% \mathrm{H}_{2} \mathrm{O}_{2}$ at the temperature of $25 \pm 2{ }^{\circ} \mathrm{C}$. For photo degradation, the tablet powder equivalent to $325 \mathrm{mg}$ of aspirin and $40 \mathrm{mg}$ of omeprazole was exposed to direct 
sunlight for $24 \mathrm{~h}$. Thermal degradation analysis was performed by keeping the tablet powder (325 $\mathrm{mg}$ of aspirin and $40 \mathrm{mg}$ of omeprazole) in a thermostated oven at $105^{\circ} \mathrm{C}$ for $30 \mathrm{~min}$.

After exposing aspirin and omeprazole to the forced degradation conditions, proper dilutions were made with the mobile phase to obtain the solution with a concentration of $130 \mu \mathrm{g} / \mathrm{ml}$ aspirin and $16 \mu \mathrm{g} / \mathrm{ml}$ of omeprazole. These solutions were filtered through a $0.45 \mu \mathrm{m}$ pore size membrane filter and $20 \mu \mathrm{l}$ of each stress sample solution was injected into the HPLC system. The percentage degradation of aspirin and omeprazole in all the stress conditions was calculated by using a standard solution of aspirin and omeprazole at the same concentration.

Acknowledgements: The author, Gopikrishna Yenduri, would like to thank Ms. S. Gayatri for her sincere support during the work.

Author contributions: Concept - G.Y., S.N.; Design - G.Y., S.N.; Supervision - S.N.; Resource - G.Y., S.N.; Materials G.Y., S.N.; Data Collection and/or Processing - G.Y.; Analysis and/or Interpretation - G.Y., S.N.; Literature Search G.Y., S.N.; Writing - G.Y., S.N.; Critical Reviews - G.Y., S.N.

Conflict of interest: The authors declared no conflict of interest

\section{REFERENCES}

[1] Valentin F, Joseph MS. Aspirin: A historical and contemporary therapeutic overview. Circulation. 2011; 123 (7): 768 778 .

[2] Vane JR, Botting RM. The mechanism of action of aspirin. Thromb Res. 2003; 110 (5-6): 255-258.

[3] Dick S, Sushama K, Joseph Mc, Rajah K. Pharmacology of nonsteroidal antiinflammatory drugs and opioids. Semin Intervent Radiol. 2010; 27 (4): 400-411.

[4] Rod F. What are all the things that aspirin does?. BMJ. 2003; 327 (7415): 572-573.

[5] Paez Espinosa EV, Murad JP, Khasawneh FT. Aspirin: Pharmacology and clinical applications. Thrombosis. 2012; 2012: Article ID 173124.

[6] Dean L. Omeprazole Therapy and CYP2C19 Genotype. 2012 Oct 1 [Updated 2016 Mar 8]. In: Medical Genetics Summaries [Internet]. Bethesda (MD): National Center for Biotechnology Information (US); 2012.

[7] Raymond SY Tang, Justin CY Wu. Managing peptic ulcer and gastroesophageal reflux disease in elderly Chinese patients - focus on esomeprazole. Clin Interv Aging. 2013; 8: 1433-1443.

[8] Raul B, Dawn F. Diagnosis and treatment of gastroesophageal reflux disease. World J Gastrointest Pharmacol Ther. 2014; 5 (3): 105-112.

[9] Alice M, Giuseppina O. Delayed-release oral suspension of omeprazole for the treatment of erosive esophagitis and gastroesophageal reflux disease in pediatric patients: a review. Clin Exp Gastroenterol. 2010; 3: 17-25.

[10] Maliheh S, Reyhaneh S, Alireza F. Treatment of Helicobacter pylori infection: Current and future insights. World J Clin Cases. 2016; 4 (1): 5-19.

[11] http://www.centerwatch.com/drug-information/fda-approved-drugs/drug/100165/yosprala-aspirin-andomeprazole

[12] Tushar S, Kevin B, Rahul C, Udaya T, Paul AG. Efficacy of aspirin (325 mg) + omeprazole (40 mg) in treating coronary artery disease. Expert Opin Pharmacother. 2017; 18 (1): 123-131.

[13] Patta S, Afreen S, Tappa S, Nagarajan G, GnanaPrakash K, Simultaneous estimation of aspirin and omeprazole (YOSPRALA) in bulk by UV-spectroscopy. J Drug Deliv Ther. 2017; 7(3): 87-91.

[14] International Conference on Harmonization Q1A, Stability Testing of New Drug Substances and Products, ICH Secretariat, Geneva, 1993.

[15] International Conference on Harmonization Q1B, Stability testing: Photostability Testing of New Drug Substances and Products, Proceeding of the International Conference on Harmonization, Geneva, 1996.

[16] International Conference on Harmonization, ICH Guidelines, Validation of analytical procedures technical requirements for registration of pharmaceuticals for human use: Text and Methodology Q 2 (R1), International Conference on Harmonization, Geneva, Switzerland, November 2005. 